\title{
The proper college
}

\section{Mark Crouch $^{\text {a }}$}

${ }^{a}$ MD, Public Health Officer, Staff Physician, Kudjip Nazarene Hospital, In His Image International, Papua New Guinea

"The hospital is the only proper College in which to rear a true disciple of Aesculapius."

\section{Unprepared}

For a little over a year, I have known a young man from a nearby village. We will call him Endy. He first came to our district mission hospital suffering from weight loss and sores on his skin. Though we treated him, he never improved. A test for HIV confirmed my suspicion that Endy, through some poor past decisions, had contracted this incurable virus and was suffering from AIDS.

Despite my best efforts to treat him, Endy's condition deteriorated. A blood test showed that his HIV had become resistant to his medicine. An ultrasound showed disease in his liver. Endy was dying.

I pushed Endy's wheelchair back into my exam room while his uncle and sister filed in behind us. In my second language, I explained to Endy that he was about to die from AIDS, and I was powerless to save his life.

He understood, and while his uncle and sister cried, Endy showed a steely determination. He had accepted Christ during the course of his illness and felt he would soon leave his earthly form and enjoy a new, completely healthy body.

"Endy, it has been a pleasure to know you."

"Doctor, one day I will see you again."

We prayed together and I prescribed some medications to help Endy's pain and nausea.

I then continued to see patients with complicated orthopedic injuries, major obstetrical complications, and unusual tropical fevers before finishing my day meeting with a major international non-governmental organization to address our hospital's cure rates for tuberculosis.

Training in a U.S. medical school and residency could not have adequately prepared me for this kind of medicine.

\section{Background}

I recently read the latest edition of the Christian Journal for Global Health (November 2016). Many of the articles center on the topic of health education in the developing world. This topic lies close to my heart.

I currently serve at a mission hospital in a lowincome country in the Pacific. Our hospital is a churchrun facility, partnered with the national department of health, serving the rural area around us for the past 50 years. We perform surgeries, handle 24-hour emergency services, deliver babies, provide immunizations, care for HIV and tuberculosis patients, and encounter a never-ending stream of sickness in our out-patient department.

I left the United States to serve as a medical missionary with every intention of teaching. I imagined that young national physicians were just waiting for me-to mentor and disciple, to teach excellent standards of care and medicine as part of my ministry. I believed I might quickly train them to take my place and return to my home country to serve as a mission mobilizer for the next generation. Perhaps I could also serve as a financial benefactor to my hospital and successors.

I still nurture this desire. I work with a young national physician in our hospital who has embraced the challenge of caring for her people. She has a wealth of practical experience I initially lacked, despite my more "advanced" medical training. She married a fellow national surgeon, and I have watched them both prayerfully consider their future-how they might 
blend their medical care with ministry to the suffering people in their country.

I also recognize how naïve it was for me to expect that I could move to the mission field and immediately start teaching. The kind of medicine I brought with me, not to mention the culture and language I learned it in, differed significantly from the medicine I now practice every day.

In the last CJGH issue, Smith, et al. remarked, "In the last several years, there has been an increasing recognition that treating individual patients in hospitals by expatriate health care professionals is neither sustainable nor capable of building long-term capacity." A statement from the American Academy of Family Practice also prioritizes teaching over clinical medicine in global health. "In countries outside of the United States, the most critical role for a family physician is to train local health care professionals and support them in the development of family medicine programs."3

While affirming the need and value of health educators, I would caution the medical mission community not to forsake clinical medicine. Training received in the developed world cannot fully prepare physicians to teach immediately in other countries. Furthermore, to assume humbly the mantle of teacher, one must first consider if he truly understands the culture, medicine, and students he plans to instruct. Finally, the sheer volume of suffering in the world, along with Christ's example and instructions to "heal the sick," compels Christian physicians to care for patients.

\section{A Sterile Discipline}

As Shah, et al. pointed out, "Taking bio-medical and public health knowledge and the approach to medical education from a high income country (HIC) and transferring it to low income settings without contextualization can be problematic at a number of levels." 5

Medicine as it is practiced in the United States looks very different than the medicine most of the world practices - particularly in countries with limited resources, difficult social situations, and heavy burdens of disease. Those planning a career in medical education overseas do well to recognize the limitations of their own medical training. For many medical missionaries, this means reflecting on the environment in which we learned to be health professionals.

In the United States, many of the difficult cases and advanced presentations of diseases are buffered by the health system and advanced technology of the profession. Few non-surgical residents will see complicated lacerations and injuries, usually handled in the emergency or operating room. Emergency department trainees will rarely, if ever, encounter challenging obstetric cases typically triaged and managed in the maternity department. Surgical residents in the US will see greater amounts of traumatic injuries, but commonly in a well-equipped trauma bay or operating room with excellent lighting, anesthesia, diagnostic imaging, and a preserved clean field for surgery.

In other parts of the world, patients present late with diseases that often disfigures them. There are few truly clean locations in which to reduce open fractures, clamp arteries, deliver babies, or repair obstetrical lacerations. Injuries can be truly horrifying and patients are often crowded about by grieving family members soaked in blood from carrying their loved ones. The practice of medicine in these environments is often more raw than those coming from developed nations of which they are accustomed.

In short, much of the mud and blood of medicine has been autoclaved away by early presentations of disease, our excellent health system management, and the advanced technology of our hospitals. Medicine in more advanced countries of the world has become a sterile discipline.

For those who profess to teach medicine, recognizing the limitations of their own perspective is an essential step to take before instructing doctors in a totally different environment.

\section{Motivations}

"Not many of you should presume to be teachers..."6

Why do medical missionaries choose to become teachers? I would respond that in doing so, medical missionaries amplify their efforts and create a more 
sustainable impact.

Teaching medicine, particularly to national physicians or healthcare workers, results in a more amplified impact of our missionary service. Nationals possess a greater understanding of their people than expatriates. Furthermore, national physicians who remain in their country will likely outlast their teachers. They often become leaders in their nation. They go on to train the next generation of health professionals. This perpetuates the medical practices and attitudes they receive from expatriate mentors. If one could put a thousand to flight, two could put ten thousand. ${ }^{7}$

Problems arise when the value placed on sustainably educating nationals exceeds that placed on serving the needs of the people. Sustainability ought to be pursued, but only if the gains made actually fit the needs of the community. A nation will not benefit if expatriate workers create a durable cadre of physicians practicing an inappropriate or ineffective medicine. Teaching health workers overseas ought to be pursued with eyes fixed on the patients they will one day encounter. This is difficult to do without an experiential background at the patient bedside.

A fantastic health education ministry suggests in one of its resources that "all those who are skilled and experienced teachers should consider whether they can spend some time every year, or the final years of their career before retirement, working as medical teachers in developing countries." 8 While skilled and experienced teachers are needed, this ethos ought to be tailored to the medical climate of the receiving nation.

Temporary visitors serving as teachers in a foreign environment creates difficulties if they do not alter their instruction to fit the context of the receiving nation. Perhaps the focus of newly arriving health educators should be supporting the ongoing long-term efforts of workers and teachers already on the ground. More seasoned academicians from HIC offer a wealth of experience in effective teaching methods. Likely, their greatest benefit in a teaching role would be to demonstrate how medicine is best taught, rather than teaching the specifics of medicine in a setting with which they are unfamiliar.

Good learning precedes good teaching. Training in the developed world does not give license to teach that type of medical practice the world over. In fact, a perspective limited to HIC settings may work against the medical teacher. HIC physicians working overseas ought to spend a reasonable amount of time learning the medicine they want to teach. Without that experience, the motivation for teaching could become an educational paternalism-espousing great knowledge from the high vantage of "superior" training.

The greater need is not addressed by temporary visitors or retiring physicians who move overseas to teach HIC medicine, but rather physicians who are willing to shoulder clinical burdens seeing patients and learning all they can about a country's culture and illnesses. Those who do will be best positioned to adapt their own medical training into the new and difficult situations they encounter alongside national medical students and other trainees-learning and teaching together.

\section{A Sacred Place}

Christ's ministry involved mobilizing the twelve while also caring for individuals. He felt compassion - "suffered with" - those that he served. For three years, he walked the same stony roads that they did. $\mathrm{He}$ ate their food. He spoke their language. ${ }^{9} \mathrm{He}$ saw their illnesses and, for some, miraculously healed them. ${ }^{10,11}$ Christ treated individual patients alongside his disciples, who learned from His example, creating perhaps the most sustained change in the course of history. What if Christ had proclaimed the kingdom of God but never spent time personally absorbing the burdens of His broken world?

Christians do not enter the world to create better church-run programs than their secular counterparts. Christ gave no command to ensure sustainable medical care, but did demonstrate God's love by touching the suffering. We are compelled to bring the Kingdom of God in the same ways He did. With Christ as our example $^{12}$ and His commands in our hearts ${ }^{13}$, we combat the very real misery that breaks the heart of God. To the neglected and forgotten peoples of the world, a compassionate physician embracing their physical struggles is a powerful, tangible expression of the love of God in their lives. Can expatriate 
physicians neglect this incredible opportunity simply because it is unsustainable?

"Until the suffering of any and all is met with compassion and care there is a place, may I say a sacred place, at the patient bedside" 14

\section{The Blood and Mud}

The obligation of health educators remains "to teach to their students habits of reliance and to be to them examples of gentleness, forbearance and courtesy in dealing with their suffering brethren." ${ }^{15}$ [italics added] We cannot teach medicine we do not really know. We cannot expect a national medical student or resident to show Christ-like care in a terribly limited environment, with frequent devastating outcomes, if we have not first made the difficult journey ourselves. As Christians, we are compelled by the love of Christ and the suffering in the world. As physicians, we are uniquely equipped to bring demonstrations of God's kingdom into those situations. Expatriate Christian physicians working in medical missions should be examples of Christ-like care in a hurting world to those under our instruction. To teach well, let us also embrace clinical medicine as our "proper college."

\section{References}

1. Abernethy, John. Quoted in: Aequanimitas - with other addresses to medical students, nurses and practicioners of Medicine. William Osler. Second Edition. Philadelphia: P. Blakiston's Son \& Co; 1910.

2. Smith JD, Holland RP, Phillips JD, Falkenheimer SA. Mobilizing and training academic faculty for medical mission: current status and future directions. Christ J
Global Heal. Nov 2016; 3(2):168-75. http://dx.doi.org/10.15566/cjgh.v3i2.134

3. aafp.org [Internet]. American Academy of Family Practice. [Cited 2016 Nov 23, Available from: www.aafp.org/global-health/]

4. Matthew 10:8. The Holy Bible, New International Version. International Bible Society, 1984.

5. Shah V, Larson HE, Grills N, O'Neill D, Soderling M. "Exporting" medical education. Christ J Global Heal. 2016 Nov;3(2):3-5. http://dx.doi.org/10.15566/cjgh.v3i2.150

6. James 3:1. The Holy Bible. New International Version. International Bible Society. 1984.

7. Deuteronomy 32:30. The Holy Bible. New International Version. International Bible Society; 1984.

8. Morgan, H. Teaching medicine: a Christian approach. East Sussex, United Kingdom: PRIME - Partnerships in International Medical Education; 2008.

9. John 1:14. The Holy Bible. New International Version. International Bible Society. 1984.

10. John 5:2-15. The Holy Bible. New International Version. International Bible Society. 1984.

11. John 9:1-12. The Holy Bible. New International Version. International Bible Society. 1984.

12. Matthew 14:14. The Holy Bible. New International Version. International Bible Society. 1984.

13. Matthew 10:8. The Holy Bible. New International Version. International Bible Society; 1984.

14. McCoy W. Personal communication with, staff physician, Nazarene Health Ministries, November 2016

15. Osler W. Aequanimitas - with other addresses to medical students, nurses, and practicioners of Medicine. Second Edition. Philadelphia: P. Blakiston's Son \& Co; 1910 .

Peer Reviewed

Competing Interests: None declared.

Correspondence: Mark Crouch, Kudjip Nazarene Hospital, Papua New Guinea. crouchm@gmail.com

Cite this article as: Crouch M. The proper college. Christian Journal for Global Health. Mar 2017; 4(1):30-33.

(C) Crouch $\mathrm{M}$ This is an open-access article distributed under the terms of the Creative Commons Attribution License, which permits unrestricted use, distribution, and reproduction in any medium, provided the original author and source are properly cited. To view a copy of the license, visit https://creativecommons.org/licenses/by/4.0/ 